Relations industrielles

Industrial Relations

\title{
Tribute to Richard J. Long Hommage à Richard J. Long
}

\section{Marc Mentzer et Allen Ponak}

Volume 71, numéro 3, été 2016

URI : https://id.erudit.org/iderudit/1037657ar

DOI : https://doi.org/10.7202/1037657ar

Aller au sommaire du numéro

\section{Éditeur(s)}

Département des relations industrielles de l’Université Laval

ISSN

0034-379X (imprimé)

1703-8138 (numérique)

Découvrir la revue

Citer ce document

Mentzer, M. \& Ponak, A. (2016). Tribute to Richard J. Long / Hommage à Richard J. Long. Relations industrielles / Industrial Relations, 71(3), 391-392.

https://doi.org/10.7202/1037657ar

Tous droits réservés (C Département des relations industrielles de l’Université Laval, 2016
Ce document est protégé par la loi sur le droit d'auteur. L’utilisation des services d'Érudit (y compris la reproduction) est assujettie à sa politique d'utilisation que vous pouvez consulter en ligne.

https://apropos.erudit.org/fr/usagers/politique-dutilisation/ 


\section{Tribute to Richard J. Long}

Richard J. Long, a member of the journal's editorial board since 1990, passed away on May 15 at the age of 65 after a battle with pancreatic cancer. Rick held the position of Professor in the Edwards School of Business of the University of Saskatchewan.

Rick grew up in Edmonton, where he received his bachelors and MBA degrees from University of Alberta, followed by his PhD from Cornell University. He joined the University of Saskatchewan in 1977, achieving the rank of full professor in 1982 at the age of 31. His long career encompassed over 100 publications, including eight in Relations industrielles/Industrial Relations.

He was widely respected as an expert on compensation, and gave testimony as an expert witness before a committee of the Canadian Senate. Rick was the author of two books, New Office Information Technology: Human and Managerial Implications, and more recently, the textbook Strategic Compensation in Canada. In 2011, his textbook was named the "Number 1 Best Seller" on the Globe and Mail list of top business books.

His students will remember him for his course in compensation, which he designed around a complex simulation and used the TV reality show, Survivor, as the organizing theme. With many of his students, he developed mentoring relationships that lasted long beyond the student's graduation. He received the university's coveted Master Teacher Award in 2014.

In his personal life, Rick was proud of hiking the entire British Colombia segment of the Trans Canada Trail, and used his spare time to travel the world, achieving his goal of visiting as many countries as his years of age.

Rick is survived by his wife, Patricia, and three sons. The entire industrial relations community shares their loss.

\section{Marc Mentzer}

Professor, Edwards School of Business

Allen Ponak

Chairman, Editorial Board of RI/IR 


\section{Hommage à Richard J. Long}

Richard J. Long, membre du comité éditorial de la revue depuis 1990, est décédé le 15 mai dernier à l'âge de 65 ans, après un combat contre le cancer du pancréas. Richard était professeur à l'Edwards School of Business de I'Université de la Saskatchewan.

Richard a grandi à Edmonton, où il a obtenu son baccalauréat et son MBA de I'Université d'Alberta, suivis de son Ph. D. de I'Université Cornell. II s'est joint à I'Université de la Saskatchewan en 1977, atteignant le rang de professeur titulaire en 1982, à l'âge de 31 ans. Sa longue carrière englobe plus d'une centaine de publications, dont huit parues dans la revue Relations industrielles/Industrial Relations.

II était largement respecté en tant qu'expert en rémunération et il a, en outre, témoigné à titre d'expert sur cette question devant un comité du sénat canadien. Richard est l'auteur de deux ouvrages : New Office Information Technology: Human and Managerial Implications; et, plus récemment, du manuel intitulé Strategic Compensation in Canada. En 2011, cet ouvrage a été répertorié comme « premier parmi les meilleurs manuels dans le domaine des affaires » par le Globe and Mail.

Ses étudiants se souviendront de lui pour son cours en gestion de la rémunération, qu'il avait conçu autour d'une simulation complexe, en se servant de l'émission de télé-réalité Survivor comme thème central. II a développé, auprès de plusieurs de ses étudiants, des relations de mentorat qui se sont prolongées bien au-delà de leur graduation. En 2014, I'Université de la Saskatchewan lui a, d'ailleurs, décerné le convoité Master Teacher Award.

Dans sa vie personnelle, Richard se faisait une fierté d'avoir parcouru à pied tout le segment de la Colombie-Britannique du Sentier transcanadien. De plus, il passait ses principaux moments de loisirs à parcourir le monde, réalisant son but d'avoir visité autant de pays que le chiffre de son âge.

Au terme de cette terrible maladie, Richard laisse dans le deuil sa femme, Patricia, et ses trois garçons. La communauté des relations industrielles partage leur peine.

\section{Marc Mentzer}

Professeur, Edwards School of Business

\section{Allen Ponak}

Président du Comité de rédaction de RI/IR 